\title{
KERAGAAN PROSES PEMBELAJARAN PENYULUH PERTANIAN DALAM PENDIDIKAN TERBUKA DAN JARAK JAUH
}

\author{
Nurul Huda \\ Ludivica Endang Setijorini \\ Diarsi Eka Yani \\ Idha Farida \\ FMIPA Universitas Terbuka \\ e-mail: nurul@ecampus.ut.ac.id
}

\begin{abstract}
Agricultural extension workers who study at Universitas Terbuka (UT), which is a distance education institution, were to obtain the necessary competencies. By studying at UT, they can improve their competencies without leaving their duties. The purpose of this study was to analyze the profile of learning process of agricultural extension workers in distance education, particularly in terms of interaction with modules, tutorial activities, the scope of learning materials, independent learning, and learning facilities. Designed as an exploratory research, this study was supported by qualitative approach to obtain information that was not obtained through surveys. Respondents were agricultural extension workers in the regions of Bengkulu, Samarinda, Serang, Pontianak, Jambi, Jakarta, and Bogor. The data collected in this study were primary and secondary data. Primary data were collected using a questionnaire and indepth interviews using interview guidelines. Secondary data were obtained through the collection of documentation. Quantitative data were analyzed using descriptive statistical analysis, while qualitative information was analyzed qualitatively. The results indicated that the profile of the learning process of agricultural extension workers graduated from distance education is quite good, as seen from the high-intensity interactions between agricultural extension workers with learning materials or modules. Their participation in tutorials were also good, especially in face to face tutorials. Online tutorials were generally not been widely used. The scope of learning materials also need to accommodate in accordance to the needs of their independent learning. However, to improve the quality of service, there are several things in the learning process that needs to be addressed, such as learning facilities and interaction with modules.
\end{abstract}

Keywords: agricultural extension worker, distance education, learning process, profile

\begin{abstract}
ABSTRAK
Para penyuluh belajar di Universitas Terbuka (UT), yang merupakan institusi pendidikan jarak jauh, untuk mendapatkan kompetensi yang dibutuhkan. Dengan belajar di UT, penyuluh dapat meningkatkan kompetensinya tanpa meninggalkan tugas pekerjaannya. Tujuan penelitian adalah menganalisis keragaan proses pembelajaran penyuluh pertanian dalam sistem belajar jarak jauh, khususnya dalam hal interaksi penyuluh dengan modul, partisipasinya dalam kegiatan tutorial, cakupan materi dalam kurikulum, kemandirian belajar, dan pemanfaatan fasilitas belajar. Rancangan penelitian ini adalah exploratory research, didukung dengan pendekatan kualitatif untuk memperoleh informasi yang tidak
\end{abstract}


diperoleh melalui survei. Sampel penelitian ini adalah penyuluh di wilayah Bengkulu, Samarinda, Serang, Pontianak, Jambi, Jakarta, dan Bogor. Data yang dikumpulkan dalam penelitian ini adalah data primer dan data sekunder. Data primer dikumpulkan dengan menggunakan kuesioner melalui survei dan wawancara mendalam. Data sekunder diperoleh melalui pengumpulan dokumentasi dengan cara mencatat data yang tersedia di instansi-instansi, dan kajian pustaka yang relevan dengan penelitian. Data kuantitatif dianalisis menggunakan analisis statistika deskriptif, sedangkan informasi kualitatif dianalisis secara kualitatif. Hasil penelitian menunjukkan bahwa keragaan proses pembelajaran penyuluh pertanian lulusan pendidikan jarak jauh UT cukup baik, yang terlihat dari intensitas interaksi yang tinggi antara penyuluh dengan bahan belajar atau modul. Disamping itu, partisipasi penyuluh dalam kegiatan tutorial juga baik, khususnya pada kegiatan tutorial tatap muka. Tutorial online umumnya belum banyak dimanfaatkan penyuluh mengingat ketika mereka belajar dulu layanan tutorial online yang disediakan UT masih terbatas. Kurikulum yang digunakan juga sudah mengakomodasi kebutuhan penyuluh yang mendukung kemandirian belajar mereka. Namun demikian, untuk meningkatkan kualitas layanan yang lebih baik, ada beberapa hal dalam proses pembelajaran yang perlu dibenahi, yaitu fasilitas belajar dan interaksi dengan bahan ajar.

Kata kunci: keragaan, pendidikan jarak jauh, penyuluh, proses pembelajaran

Universitas Terbuka sebagai Perguruan Tinggi dengan sistem pendidikan Terbuka dan Jarak Jauh (PTTJJ) telah mengembangkan program studi penyuluhan dan komunikasi pertanian pada tingkat sarjana (sekarang menjadi Program Studi Agribisnis, mengikuti kodifikasi program studi). Program tersebut bertujuan untuk mengakomodasi kebutuhan para profesional penyuluh pertanian yang ingin mengembangkan diri namun terhambat oleh lokasi kerja mereka yang umumnya berada di pelosok desa. Dengan karakteristik UT sebagai PTTJJ, penyuluh yang mengikuti pendidikan di UT, dimungkinkan untuk dapat mengikuti pendidikan yang bermutu tanpa meninggalkan tugas dan kewajibannya sebagai penyuluh. Mereka belajar di UT untuk mendapatkan kompetensi yang dibutuhkan melalui mata kuliah-mata kuliah yang mendukung pencapaian kompetensi yang diharapkan. Kompetensi pembelajaran merupakan faktor penting dalam proses belajar karena merupakan capaian hasil belajar seperti yang disebutkan oleh Spencer dan Spencer (1993). Hal senada dinyatakan Mulyasa (2002) yang menyebutkan bahwa kompetensi yang harus dikuasai oleh pelajar perlu dinyatakan sedemikian rupa agar dapat dinilai, sebagai wujud hasil belajar yang mengacu pada pengalaman langsung. Dengan demikian, dalam pembelajaran yang dirancang berbasis kompetensi, penilaian tidak dilakukan berdasarkan pertimbangan objektif. Stone dan Bieber (1997) juga menyebutkan bahwa model pembelajaran berbasis kompetensi merupakan alat pengambil keputusan yang ampuh.

Penyuluh yang menjadi mahasiswa UT dituntut untuk mampu belajar mandiri, yaitu belajar atas prakarsa atau inisiatif sendiri. Belajar mandiri dapat dilakukan secara sendiri ataupun berkelompok. Bahan ajar yang digunakan dalam sistem pendidikan jarak jauh telah dirancang sedemikian rupa sehingga berperan sebagai pengganti dosen, yang dapat membantu mahasiswa belajar secara mandiri. Disamping memanfaatkan bahan ajar UT sebagai sumber belajar, mahasiswa dapat memanfaatkan sumber belajar lainnya.

Program Studi S1 Penyuluhan dan Komunikasi Pertanian UT (sekarang namanya menjadi program studi S1 Agribisnis sesuai dengan kebijakan kodifikasi program studi dari DIKTI) mulai 
beroperasi pada tahun 2004. Dalam perjalanan beroperasi selama 13 tahun, tercatat sudah ada 2.243 orang lulusan, yang terdiri atas 1.725 orang lulusan dari bidang minat pertanian, 208 orang lulusan dari bidang minat peternakan, dan 376 orang lulusan dari bidang minat perikanan. Data mahasiswa registrasi pada PS Agribisnis pada masa registrasi 2016.2 tercatat sebanyak 2.309 orang lulusan yang terdiri atas 1.727 orang lulusan bidang minat pertanian, 299 orang lulusan bidang minat peternakan, dan 217 orang lulusan bidang perikanan (FMIPA, 2016). Jumlah mahasiswa ini cukup potensial, dan cenderung bertambah mengingat masih banyak penyuluh yang belum mendapatkan kesempatan untuk meningkatkan pendidikannya ke jenjang sarjana (S-1).

Potensi ini perlu didukung oleh data dan informasi tentang keragaan proses pembelajaran penyuluh di UT. Hal ini penting untuk diketahui mengingat keragaan proses pembelajaran merupakan profil atau potret dari proses pembelajaran penyuluh selama belajar di UT. Terkait dengan hal tersebut, maka yang menjadi permasalahan adalah sejauhmana keragaan proses pembelajaran penyuluh di Universitas Terbuka, apakah sudah sesuai dengan kebutuhan penyuluh sebagai mahasiswa? Artikel ini secara umum bertujuan untuk menganalisis keragaan proses pembelajaran penyuluh dalam PTTJJ, khususnya terkait dengan interaksi mereka dengan modul, kegiatan tutorial, cakupan materi belajar, kemandirian belajar, serta fasilitas belajar yang diberikan.

\section{METODE}

Penelitian dilakukan dengan menggunakan rancangan penelitian exploratory research, yaitu penelitian yang bertujuan untuk menggali fenomena keragaan proses pembelajaran penyuluh lulusan UT. Disamping melakukan pendekatan kuantitatif dengan metode survei, penelitian juga didukung dengan informasi kualitatif dalam upaya memperoleh penjelasan yang tidak diperoleh melalui survei.

Populasi penelitian ini adalah penyuluh lulusan Program Studi S-1 Agribisnis Universitas Terbuka. Sedangkan yang menjadi responden penelitian adalah penyuluh alumni UT yang berasal dari wilayah Bengkulu, Samarinda, Serang, Pontianak, Jambi, Jakarta, dan Bogor. Untuk memperkaya hasil penelitian, wawancara mendalam (Indepth interview) juga dilakukan kepada beberapa informan kunci.

Data yang dikumpulkan terdiri atas data primer dan data sekunder. Data primer merupakan data yang langsung dikumpulkan dari setiap individu anggota populasi yang menjadi sampel penelitian sejumlah 206 orang penyuluh alumni UT. Data primer dikumpulkan melalui survei terhadap responden penelitian dengan menggunakan kuesioner, sedangkan wawancara mendalam dilakukan dengan menggunakan pedoman wawancara. Penyuluh alumni UT diminta untuk mengisi pengalaman mereka ketika belajar di UT. Data sekunder dikumpulkan dari hasil-hasil penelitian yang sudah ada dan kajian pustaka yang relevan dengan penelitian, serta data yang dimiliki lembaga terkait yaitu data jumlah mahasiswa dan alumni UT dari hasil penelitian terdahulu. Data kuantitatif dianalisis dengan menggunakan statistika deskriptif, sedangkan informasi kualitatif dianalisis secara kualitatif.

\section{HASIL DAN PEMBAHASAN}

Efisiensi belajar dipengaruhi oleh beberapa faktor (Padmowiharjo, 2008). Dalam konteks tulisan ini, faktor-faktor tersebut diadaptasi sesuai dengan pendidikan penyuluhan dalam sistem belajar jarak jauh yang diantaranya adalah interaksi dengan modul, kegiatan tutorial, cakupan materi, kemandirian belajar, dan fasilitas belajar. 


\section{Intensitas Interaksi Penyuluh dengan Bahan Ajar}

Secara umum, interaksi penyuluh alumni dengan bahan ajar tergolong sedang (69\%) seperti yang terlihat pada Gambar 1, dengan nilai rataan skor 68,47 (Tabel 1). Tingkat interaksi dengan bahan ajar tersebut ditandai dengan jumlah waktu rata-rata membaca bahan ajar (modul), waktu rata-rata untuk mengerjakan latihan soal dalam modul, serta keterbacaan materi yang disampaikan, yang juga tergolong sedang. Kondisi ini disebabkan penyuluh belajar di UT sambil bekerja melaksanakan tugasnya sebagai penyuluh. Disamping itu, penyuluh juga mempunyai tanggung jawab keluarga yang harus diperhatikan. Untuk itu, penyuluh harus dapat mengelola waktu belajarnya dengan baik.

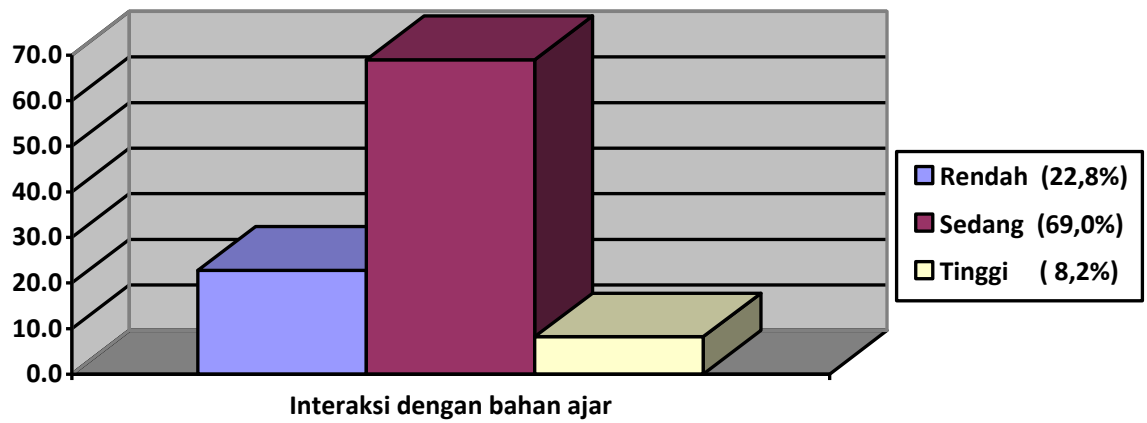

Gambar 1. Tingkat interaksi dengan bahan ajar

Dari paparan tersebut dapat dikatakan bahwa intensitas belajar penyuluh dengan membaca modul masih perlu ditingkatkan. Penyuluh harus dapat mengalokasikan waktu belajar minimal 30 jam per minggu agar setara dengan alokasi belajar mahasiswa di perguruan tinggi tatap muka. Hal ini berarti, agar pencapaian hasil belajar penyuluh di masa datang menjadi lebih baik, sehingga UT ke depan harus memberikan program yang memotivasi mahasiswa untuk meningkatkan intensitasnya dalam membaca modul.

Tabel 1. Rataan Skor Jumlah Waktu Rata-Rata untuk Membaca Modul, Mengerjakan Latihan Soal dalam Modul, dan Tingkat Keterbacaan Materi Modul.

\begin{tabular}{lrrc}
\hline \multicolumn{1}{c}{ Indikator } & Minimum & Maksimum & Rataan \\
\hline Jumlah waktu rata-rata membaca modul & 0,00 & 100,00 & 66,99 \\
Jumlah waktu rata-rata mengerjakan soal & 33,33 & 100,00 & 66,50 \\
Keterbacaan materi & 0,00 & 100,00 & 66,50 \\
Daya tarik materi yang disajikan & 33,33 & 100,00 & 73,52 \\
\hline Total rataan skor & 16,67 & 100,00 & 68,47 \\
\hline Keterangan: rendah (skor 0-50), sedang (skor 51-75), tinggi (skor 76-100) & &
\end{tabular}

Daya tarik materi yang ada dalam modul merupakan hal yang dianggap baik oleh penyuluh, yang ditunjukkan oleh nilai rataan yang tergolong sedang, yaitu 73,52 (Tabel 1). Keadaan ditambah belajar cukup menggembirakan mengingat modul UT merupakan acuan mahasiswa dalam belajar, yang dapat berperan sebagai pengganti dosen.

Dari hasil wawancara mendalam dengan alumni UT dapat diketahui bahwa tingkat interaksi mereka dengan modul yang masih kurang optimal didasari alasan bahwa mereka sharing (saling 
berbagi) dalam pembelian modul. Sehingga tidak semua modul mereka miliki. Mahasiswa seringkali menggunakan modul secara bergantian. Beberapa ringkasan materi modul sempat mereka buat dalam upaya memahami modul. Mereka menyarankan UT untuk memberi materi modul yang lebih ringkas, juga ditambah dengan memberikan kata kunci dari materi yang diberikan.

\section{Kegiatan Tutorial}

Sebagian besar penyuluh yang sudah lulus sebagai responden mengikuti kegiatan tutorial, terutama kegiatan tutorial tatap muka. Persentase penyuluh yang mengikuti kegiatan tutorial tergolong sedang hingga tinggi yaitu 93,7 persen (Gambar 2 dan Tabel 2). Hal tersebut disebabkan keikutsertaan tutorial oleh penyuluh, mahasiswa Program Studi S-1 Agribisnis tidak bersifat wajib. Sedangkan tutorial tatap muka mahasiswa di program pendidikan dasar pada Fakultas Keguruan dan IImu Pendidikan (FKIP) dan program Pascasarjana UT wajib diikuti. Artinya tutorial tatap muka merupakan kegiatan yang diminati penyuluh karena dianggap penting dalam membantu pemahaman belajarnya, walaupun sebenarnya tidak bersifat wajib. Kegiatan tutorial tatap muka diperlukan sekili karena penyuluh mendapatkan bantuan belajar dari tutor berupa penjelasan tentang materi mata kuliah yang dianggap sulit sehingga membantu pemahaman belajar penyuluh.
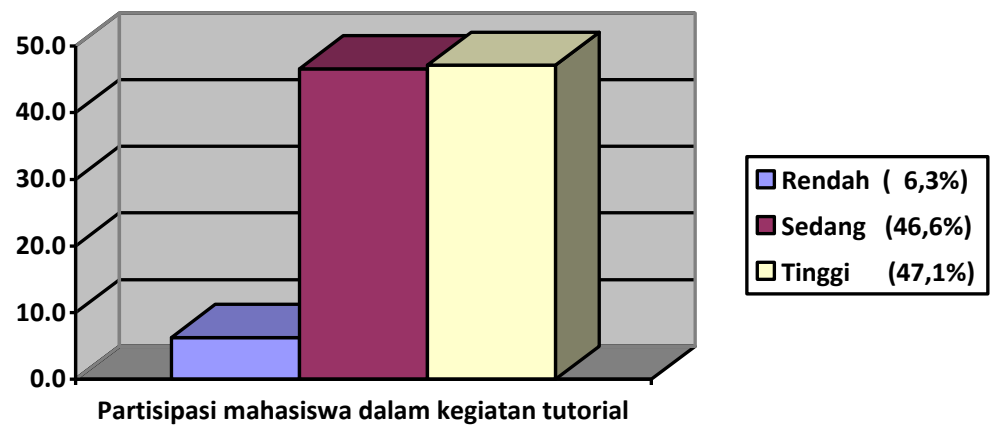

Gambar 2. Tingkat partisipasi mahasiswa dalam kegiatan tutorial tatap muka

Tabel 2. Rataan Skor Keikutsertaan dalam Tutorial Tatap Muka, Alokasi Waktu, Peran Tutor, dan Manfaat Tutorial.

\begin{tabular}{lccc}
\hline \multicolumn{1}{c}{ Indikator } & Minimum & Maksimum & Rataan \\
\hline Keikutsertaan dalam tutorial tatap muka & 33,33 & 100,00 & 77,34 \\
Alokasi waktu keikutsertaan & 33,33 & 100,00 & 69,75 \\
Peran tutor & 33,33 & 100,00 & 75,65 \\
Manfaat tutorial tatap muka & 33,33 & 100,00 & 79,02 \\
\hline Total kegiatan tutorial tatap muka & 29,63 & 100,00 & 74,45 \\
\hline
\end{tabular}

Keterangan: rendah (skor 0-50), sedang (skor 51-75), tinggi (skor 76-100)

Tingkat partisipasi penyuluh alumni dalam kegiatan tutorial tatap muka yang tergolong tinggi ditunjukkan oleh rataan skor mereka dalam keikusertaan tutorial, alokasi waktu dalam tutorial, peran tutor, dan manfaat tutorial seperti yang nampak pada Tabel 2. Rataan skor tersebut berkisar antara 69,75 hingga 79,02 . Hal ini menunjukkan kegiatan tutorial tatap muka dibutuhkan penyuluh alumni UT terutama karena peran tutor dianggap dapat: (a) memperjelas uraian materi dalam modul; (b) 
meningkatkan minat penyuluh alumni untuk mempelajari materi yang ada dalam modul; (c) meningkatkan kemampuan penyuluh alumni dalam membaca materi modul; (d) memberikan materi tutorial yang sesuai dengan materi modul.

Kegiatan tutorial tatap muka juga dianggap bermanfaat dalam mempermudah mahasiswa mengerjakan soal ujian dan membantu dalam memperoleh hasil belajar yang baik.

Penyuluh alumni UT yang tidak ikut kegiatan tutorial tatap muka disebabkan oleh ketersediaan waktu dalam pemenuhan tugas kerja. Hal ini dapat dimaklumi mengingat sebagian besar penyuluh bekerja, yang mungkin mengalami kesulitan dalam membagi waktu antara belajar dan bekerja. Kondisi ini mungkin menyebabkan interaksi sosial penyuluh dengan lingkungannya juga kurang seperti temuan penelitian Huda (2015) yang menyebutkan bahwa kompetensi sosial penyuluh alumni UT masih tergolong kurang. Untuk meningkatkan kompetensi ini, perlu kiranya bagi penyuluh untuk berupaya berinteraksi dengan rekan sejawat, misalnya dengan cara mengikuti kegiatan tutorial tatap muka.

Penyuluh alumni UT yang mengikuti kegiatan tutorial umumnya menggunakan jenis tutorial tatap muka, sedangkan penyuluh alumni lainnya menggunakan jenis tutorial tertulis dan tutorial melalui internet. Maknanya, jenis tutorial tatap muka lebih diminati penyuluh dibandingkan dengan jenis tutorial tertulis dan tutorial melalui internet. Hal ini disebabkan dalam tutorial tatap muka penyuluh dapat berinteraksi dan berdiskusi langsung dengan tutor dan rekan sejawatnya. Temuan ini sejalan dengan pendapat Puspitasari dan Huda (2000) yang menyatakan bahwa melalui tutorial tatap muka mahasiswa dapat bertukar pikiran dengan mahasiswa lainnya dan dapat mengurangi rasa keterasingan.

Tabel 3. Sebaran Penyuluh Alumni UT Menurut Keikutsertaan dalam Tutorial, Alokasi Waktu Tutorial, Peran Tutor, dan Manfaat Tutorial.

\begin{tabular}{lcc}
\hline \multicolumn{1}{c}{ Indikator } & Kategori & Persentase \\
\hline Keikutsertaan dalam tutorial & Rendah & 7,80 \\
& Sedang & 52,40 \\
& Tinggi & 39,80 \\
\hline Alokasi waktu tutorial & Rendah & 15,10 \\
& Sedang & 60,50 \\
& Tinggi & 24,40 \\
\hline Peran tutor & Rendah & 9,03 \\
& Sedang & 63,32 \\
& Tinggi & 27,65 \\
\hline Manfaat tutorial & Rendah & 8,13 \\
& Sedang & 51,90 \\
& Tinggi & 40,00 \\
\hline Total kegiatan tutorial & Rendah & 5,30 \\
& Sedang & 46,60 \\
& Tinggi & 47,10 \\
\hline
\end{tabular}

Hasil wawancara mendalam (dengan sampel irforman kunci di wilayah Jakarta Barat) terkait dengan kegiatan tutorial menunjukkan bahwa jenis tutorial yang diikuti adalah Tutorial Tatap Muka (TTM). Semua mata kuliah mereka ikuti TTM nya. Kegiatan TTM tersebut mereka laksanakan di UNJ 
Rawamangun, Jakarta. Hal ini berarti TTM dianggap bermanfaat bagi penyuluh dalam proses belajar mereka di UT. Mereka pernah mengalami mendapatkan tutor yang tidak menguasai materi yang ditutorialkan. Sampai akhirnya mereka mencari pengganti tutor yang lebih menguasai materi untuk membantu mereka mempelajari materi modul. Di sisi lain, pada umumnya mereka tidak mengikuti tutorial online, dengan alasan mereka merasa gaptek atau tidak terbiasa dengan bekerja dengan komputer. Ditambah lagi dengan faktor akses jaringan yang sering bermasalah, seperti temuan penelitian yang dilakukan oleh Wahyuningsih, Rusli, \& Bintari (2015).

Dari paparan tersebut dapat dikatakan bahwa kegiatan tutorial yang diselenggarakan UT merupakan hal yang dianggap membantu mereka dalam memahami materi belajar. Oleh karena itu, ke depan UT perlu lebih meningkatkan kualitas layanan tutorial kepada mahasiswa, terutama kualifikasi tutor yang benar-benar menguasai materi di bidangnya masing-masing.

\section{Cakupan Mata Kuliah}

Mahasiswa belajar di UT untuk mendapatkan kompetensi yang dibutuhkan melalui mata kuliah-mata kuliah yang ada dalam kurikulum program studi. Mata kuliah tersebut mengacu pada materi yang berkaitan dengan peningkatan tiga kelompok kompetensi sesuai dengan Standar Kompetensi Kerja Nasional Indonesia (SKKNI) (Menakertrans, 2010) yaitu Kompetensi Umum/Dasar, Kompetensi Inti/Fungsional dan Kompetensi Khusus/Spesialisasi (Rustadi, 2011).

Menurut penyuluh yang sudah lulus dari prodi Agribisnis secara umum cakupan materi mata kuliah yang ada dalam kurikulum UT tergolong sedang, yaitu 53,2\% untuk kompetensi dasar, serta masing-masing 49,3\% untuk kompetensi professional dan kompetensi khusus (Gambar 3), dengan rataan skor 85,09 (Tabel 4). Hal ini karena cakupan mata kuliah dianggap dapat meningkatkan kompetensi dasar, kompetensi fungsional, dan kompetensi khusus. Hal ini berarti, cakupan materi yang ada dalam kurikulum sudah memadai karena dapat memenuhi capaian dari ke tiga jenis kompetensi tersebut. Namun demikian, tentu saja materi mata kuliah tersebut tetap perlu mengikuti perkembangan IPTEKS, sehingga perlu direvisi secara periodik.

Tabel 4. Sebaran Skor Cakupan Mata Kuliah.

\begin{tabular}{lccc}
\hline \multicolumn{1}{c}{ Indikator } & Minimum & Maximum & Mean \\
\hline Kompetensi dasar & 33,33 & 100,00 & 87,31 \\
Kompetensi fungsional & 33,33 & 100,00 & 86,01 \\
Kompetensi khusus & 33,33 & 100,00 & 81,95 \\
\hline Total kompetensi & 33,33 & 100,00 & 85,09 \\
\hline
\end{tabular}

Pada Tabel 4 dapat dilihat bahwa nilai rataan skor cakupan mata kuliah berkisar antara 81,95 hingga 87,31 . Nilai rataan terendah ada pada kompetensi khusus, sedangkan yang tertinggi ada pada kompetensi dasar. Hal ini berarti bahwa cakupan mata kuliah untuk meningkatkan kompetensi khusus perlu mendapat perhatian untuk perbaikan, sedangkan untuk peningkatan kompetensi dasar dan kompetensi profesional dianggap sudah mencukupi.

Sebagian besar penyuluh sebagai sampel menyatakan bahwa dari keseluruhan mata kuliah yang ada dalam kurikulum Program Studi S1 Agribisnis UT, cakupan materinya terkait dengan tugas penyuluh dalam merencanakan, melaksanakan, dan mengevaluasi kegiatan penyuluhan tergolong tinggi. Artinya, cakupan materi mata kuliah yang ada dalam kurikulum UT cukup sesuai dengan tugas pokok penyuluh dalam melaksanakan kegiatan penyuluhan. 
Dari hasil wawancara mendalam dengan penyuluh alumni UT dapat diketahui bahwa mata kuliah yang ada dalam kurikulum UT sudah mencakup materi yang diperlukan bagi penyuluh dalam melaksanakan kegiatan penyuluhan baik dalam hal merencanakan, melaksanakan, maupun mengevaluasi kegiatan penyuluhan.

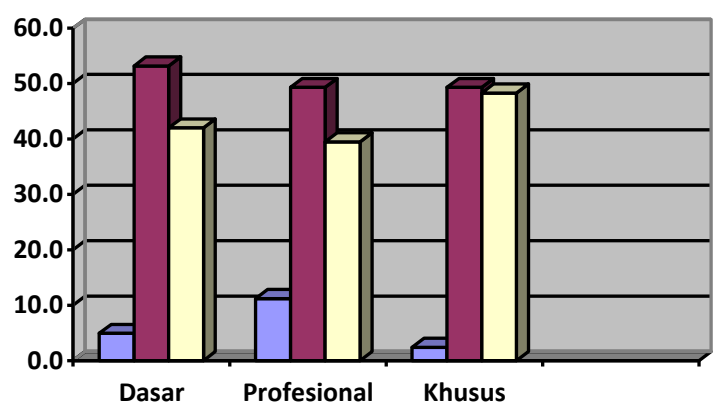

Gambar 3. Tingkat cakupan mata kuliah

Secara umum dikatakan bahwa materi yang ada dalam kurikulum dapat digunakan untuk: meningkatkan kompetensi dasar penyuluh, meningkatkan kompetensi profesional penyuluh, serta meningkatkan kompetensi khusus penyuluh. Materi yang ada dalam kurikulum menurut mereka sudah baik. Bahkan mata kuliah statistik juga berguna bagi mereka dalam melaksanakan tugasnya sebagai penyuluh.

\section{Kemandirian belajar}

Kemandirian belajar adalah kondisi aktivitas belajar yang mandiri yang tidak tergantung pada orang lain, memiliki kemauan serta bertanggung jawab sendiri dalam menyelesaikan masalah belajarnya. Kemandirian belajar akan terwujud apabila mahasiswa secara mndiri aktif mengontrol sendiri segala sesuatu yang dikerjakan, mengevaluasi, dan selanjutnya merencanakan sesuatu yang lebih dalam pembelajaran yang dilalui dan mahasiswa juga mau aktif dalam proses pembelajaran. Kemandirian belajar juga dapat diartikan pemberian kesempatan belajar dari keberhasilan dan kegagalannya dalam memberi respon terhadap perubahan, sehingga mampu untuk mengendalikan masa depannya.

Tingkat kemandirian belajar penyuluh alumni UT tergolong sedang hingga tinggi (99,5\%), yaitu hampir seratus persen, seperti yang dapat dilihat pada Gambar 4. Hal ini menunjukkan bahwa UT sebagai perguruan tinggi yang menggunakan sistem belajar jarak jauh dapat membentuk mahasiswanya menjadi pembelajar mandiri. Kemandirian belajar memang dikondisikan untuk mahasiswa yang mengikuti proses pembelajaran di UT, mengingat tempat tinggal mereka yang tersebar di seluruh pelosok nusantara, bahkan juga yang berdomisili di luar negeri.

Sistem belajar di UT pada dasarnya adalah belajar mandiri, dalam hal ini bahan ajar mempunyai peran yang strategis, bahkan dapat dikatakan menentukan keberhasilan belajar. Hal ini karena bahan ajar merupakan media interaksi antara proses berpikir mahasiswa dengan pengetahuan yang ingin dikuasai. Dengan demikian, proses belajar akan efektif apabila hasil dan cara penulisan bahan ajar memenuhi kondisi yang mendukung interaksi. Sampai saat ini, bahan ajar cetak merupakan bahan belajar utama bagi mahasiswa UT. Karakteristik bahan ajar cetak yang mampu memuat dan mempresentasikan pengetahuan dengan lengkap tetapi juga fleksibel untuk 
digunakan kapan saja dan dimana saja merupakan kunci strategis peranan jenis bahan ajar ini (Belawati, 1999).

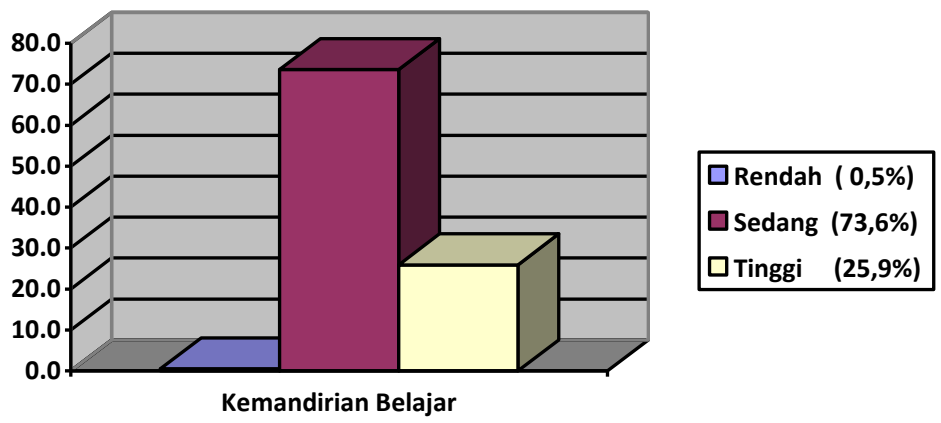

Gambar 4. Tingkat kemandirian belajar

Pada Tabel 5 dapat dilihat bahwa rataan skor tertinggi dicapai ketika mahasiswa merasa belajar adalah salah satu upaya untuk mengembangkan diri $(79,27)$. Hal ini dapat dimaklumi mengingat semakin mandiri seseorang maka upaya pengembangan dirinya akan semakin baik. Pendapat ini sejalan dengan yang dinyatakan oleh Sundayana (2016) yaitu bahwa semakin tinggi tingkat kemandirian belajar siswa, maka semakin tinggi pula kemampuan pemecahan masalah matematis siswa.

Rataan skor terendah terdapat pada keadaan dimana belajar dapat dilakukan secara sendiri semuanya $(52,90)$. Hal ini menunjukkan bahwa belajar mandiri bukan berarti harus belajar sendiri, tetapi dapat dilakukan secara berkelompok. Dengan berkelompok, mahasiswa dapat saling berdiskusi dan dapat saling membantu dalam memahai materi belajar.

Tabel 5. Rataan Skor Kemandirian Belajar.

\begin{tabular}{lrcc}
\hline \multicolumn{1}{c}{ Indikator } & Minimum & Maksimum & Rataan \\
\hline Belajar sebagai proses yang menyenangkan & 33,33 & 100,00 & 77,83 \\
Dapat mempelajari sendiri semua hal & 0,00 & 100,00 & 52,90 \\
Senang mendiskusi ide-ide & 33,33 & 100,00 & 72,96 \\
Belajar untuk mengembangkan diri & 66,66 & 100,00 & 79,27 \\
Kesulitan belajar bukan halangan & 33,33 & 100,00 & 70,48 \\
\hline Total rataan skor & 46,66 & 100,00 & 70,74 \\
\hline
\end{tabular}

Kemandirian belajar penyuluh alumni UT umumnya sudah baik. Namun demikian untuk belajar sendiri sepertinya masih merasa berat. Untuk itu mereka membentuk kelompok belajar agar dapat saling mendukung. Penyuluh alumni UT berinteraksi dengan sejawatnya atau sesama penyuluh yang menjadi mahasiswa UT terutama dalam mengikuti kegiatan kelompok belajar. Mereka ikut kelompok belajar karena dianggap dapat memudahkan diskusi dan mengerjakan tugas-tugas mata kuliah. Hal ini berarti kelompok belajar sangat dirasakan manfaatnya oleh mahasiswa dalam membantu proses belajar mereka di UT. Temuan ini sejalan dengan hasil penelitian Wahyono dalam Adnan (2004) yang menyebutkan mahasiswa berpendapat bahwa dengan adanya kelompok belajar, semangat belajar mereka bertambah, informasi tentang UT menjadi lancar, dan peserta dapat saling 
mengenal sebagai sesama mahasiswa UT. Untuk itu, mengingat berinteraksi dengan sesama sejawat yang belajar di UT merupakan hal yang bermanfaat bagi mahasiswa, maka agar pencapaian hasil belajar mahasiswa dapat lebih optimal, ke depan UT perlu lebih memotivasi mahasiswa agar dapat berinteraksi dengan sejawatnya dalam bentuk kelompok belajar. Penyuluh alumni UT yang tidak ikut kelompok belajar menyebutkan beberapa alasan mereka tidak mengikuti kegiatan tutorial. Alasan tersebut terutama karena tidak ada waktu. Penyuluh lainnya beralasan karena tempat tinggal berjauhan dan tidak ada manfaatnya.

Temuan lain menunjukkan bahwa kelompok belajar merupakan sarana yang efektif dalam membantu pencapaian hasil belajar mereka. Oleh karena itu, sesuai dengan pendapat Adnan (2004), perlu dilakukan pembinaan terhadap kelompok belajar yang sudah terbentuk agar kelompok belajar tersebut dapat tetap eksis dan dapat memberi manfaat kepada para anggotanya.

Dari hasil wawancara mendalam dengan penyuluh alumni dapat diketahui bahwa interaksi dengan sesama penyuluh yang menjadi mahasiswa UT sangat erat terjalin. Umumnya mereka selalu bersama dan berkelompok dalam setiap kegiatan belajar. Terlebih lagi, bagi penyuluh alumni yang lokasi tempat tinggalnya berdekatan umumnya mereka ada pertemuan bulanan yang sering juga dimanfaatkan untuk berdiskusi dan mencari pemecahan masalah belajar yang dihadapi. Menurut mereka, dengan berkelompok sangat membantu mereka dalam keberhasilan belajar karena dengan berkelompok mereka dapat berdiskusi dan saling bertukar informasi. Disamping itu, dengan berkelompok juga memungkinkan mereka untuk melakukan praktikum secara bersama, khususnya untuk mata kuliah yang ada tugas praktikumnya.

Dari paparan tersebut diketahui bahwa tingkat interaksi penyuluh alumni dalam kelompok belajar cukup baik. Hal ini tercermin dari adanya pertemuan rutin untuk berdiskusi tentang permasalahan yang ditemui dalam belajar. Oleh karena itu, kelompok belajar sangat bermanfaat dalam membantu keberhasilan belajar mereka.

\section{Fasilitas Belajar}

Fasilitas belajar yang dimaksud di sini bersifat umum, misalnya ruangan yang disediakan untuk kegiatan tutorial, atau sumber belajar lainnya yang mendukung. Terkait dengan hal tersebut, responden menyatakan bahwa secara umum fasilitas belajar yang ada saat ini tergolong sedang $(58,2 \%)$, baik ditinjau dari segi kekiniannya (up-to-date), kenyamanan, maupun kecukupannya. Rataan skor 62,68 seperti yang terlihat pada Tabel 6, menunjukkan bahwa kualitas fasilitas belajar yang ada dianggap masih kurang. Hal ini mungkin disebabkan oleh domisili mahasiswa yang umumnya jauh dari UPBJJ menyebabkan mereka tidak dapat menggunakan fasilitas belajar ini. Walaupun sebenarnya jika ditinjau dari sarana dan prasarana ruang tutorial sudah memadai mengingat UT memiliki ruangan yang cukup nyaman untuk kegiatan tersebut di UPBJJ-UT.

Tabel 6. Rataan Skor Fasilitas Belajar Ditinjau dari Segi Kekinian, Kenyamanan, dan Kecukupan.

\begin{tabular}{lccc}
\hline \multicolumn{1}{c}{ Indikator } & Minimum & Maksimum & Rataan \\
\hline Kekinian & 0,00 & 100,00 & 64,01 \\
Kenyamanan & 0,00 & 100,00 & 64,17 \\
Kecukupan & 0,00 & 100,00 & 59,86 \\
\hline Total fasilitas belajar & 0,00 & 100,00 & 62,68 \\
\hline
\end{tabular}


Berdasarkan Tabel 6 dapat dilihat bahwa nilai rataan skor terendah adalah yang terkait dengan kecukupan fasilitas belajar yaitu 59,86, sedangkan untuk faktor kekinian dan kenyamanan, nilai rataan skor lebih baik yaitu masing-masing 64,01 dan 64,17. Hal ini berarti faktor kecukupan fasilitas belajar dalam arti kuantitas dan kualitas perlu menjadi perhatian utama untuk peningkatan kualitasnya di masa mendatang.

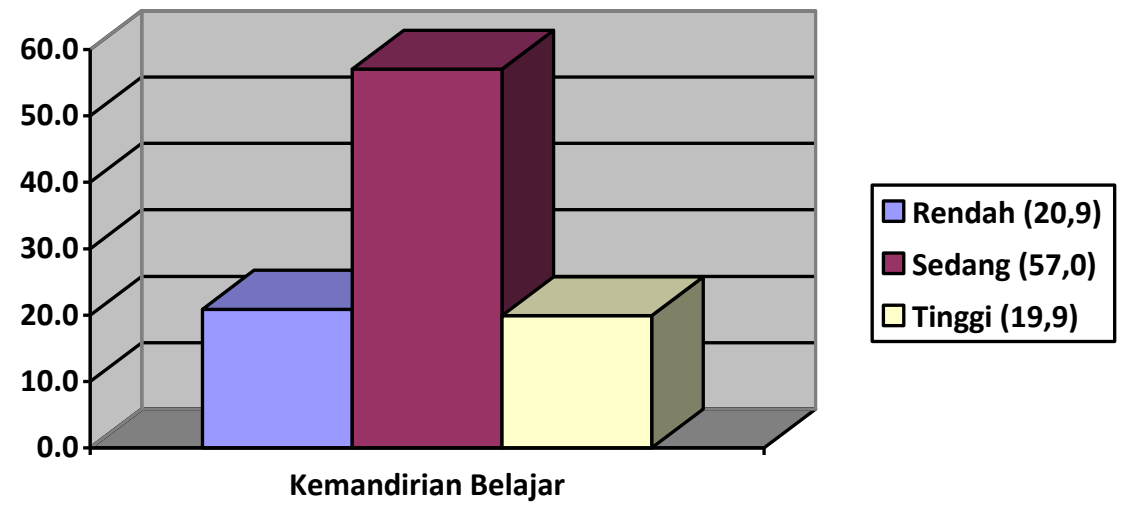

Gambar 5. Tingkat Kualitas Fasilitas Belajar

Hasil wawancara mendalam menunjukkan bahwa mahasiswa lulusan prodi Agribisnis yang berprestasi sebagai penyuluh menyatakan fasilitas belajar yang diberikan UT sudah cukup baik. Sejalan dengan itu, memang UT sudah memberikan fasilitas yang memadai di semua UPBJJ-UT, khususnya dalam penyediaan ruangan untuk kegiatan tutorial.

\section{SIMPULAN}

Secara umum, dari paparan tersebut di atas dapat disimpulkan bahwa keragaan proses pembelajaran penyuluh di UT adalah sebagai berikut.

1) Interaksi penyuluh dengan bahan ajar tergolong sedang yang menunjukkan bahwa modul sebagai bahan ajar dibutuhkan oleh penyuluh dalam membantu mereka belajar.

2) Sebagian besar penyuluh mengikuti kegiatan tutorial, terutama tutorial tatap muka karena dinilai cukup bermanfaat dalam membantu pemahaman belajarnya.

3) Cakupan materi mata kuliah dalam kurikulum UT dinilai penyuluh sudah memenuhi kebutuhan mereka dalam meningkatkan kompetensi dasar, kompetensi fungsional, dan kompetensi khusus penyuluh.

4) Kemandirian belajar merupakan keragaan yang paling baik dengan kategori sedang hingga tinggi (99,5 persen) yang menunjukkan bahwa UT mampu membuat penyuluh menjadi mahasiswa yang mampu belajar secara mandiri.

5) Fasilitas belajar merupakan unsur yang paling rendah skor keragaannya yang berarti penyuluh menyatakan fasilitas belajar yang diberikan masih kurang memadai.

\section{SARAN}

Dari temuan penelitian yang telah dipaparkan tersebut, beberapa saran yang dapat disampaikan adalah perlu adanya upaya peningkatan kualitas dalam hal interaksi penyuluh dengan modul, pelaksanaan kegiatan tutorial, serta fasilitas belajar. 


\section{REFERENSI}

Adnan, I. (2004). Pembinaan kelompok belajar. Di dalam: Assandhimitra dkk, editor. Pendidikan tinggi jarak jauh. Jakarta. Pusat Penerbitan Universitas Terbuka.

Belawati, T. (1999). Sejarah pemikiran pendidikan terbuka dan jarak jauh. Dalam T. Belawati (Eds.), Pendidikan terbuka dan jarak jauh. Jakarta: Universitas Terbuka.

[FMIPA-UT]. (2016). Statistik mahasiswa dan lulusan program studi Agribisnis. Jakarta: FMIPA-UT. Universitas Terbuka.

Huda, N. (2015). Open \& distance learning (ODL) and agricultural extension workers' social competence in Indonesia. Journal of education and learning (EduLearn), 9 (1); 17-24.

Menakertrans. (2010). Lampiran Keputusan Menakertrans RI no. KEP. 29/MEN/III/2010. SKKNI Penyuluh Pertanian. Jakarta: Kemenakertrans RI.

Mulyasa, E. (2002). Kurikulum berbasis kompetensi. Bandung: PT Remaja Rosdakarya.

OECD. (2007). Giving knowledge for free. The emergence of open educational resources. Pdf, diakses dari http://www.oecd.org/dataoecd/35/7/38654317.pdf.

Padmowiharjo, S. (2008). Materi pokok psikologi belajar mengajar. Jakarta: Penerbit Universitas Terbuka.

Puspitasari, K.A., \& Huda, N. (2000). Reviu hasil penelitian tentang tutorial di Universitas Terbuka. Jurnal pendidikan terbuka dan jarak jauh, 1(1); 42-57.

Rustadi. (2011). Standar kompetetensi kerja nasional Indonesia (SKKNI). Jakarta: Badan nasional sertifikasi profesi (BNSP).

Spencer, L.M., \& Spencer, S.M. (1993). Competence at work: Models for superior performance. New York: John Wiley \& Sons, Inc.

Stone, B.B., \& Bieber, S. (1997). Competencies: A new language for our work. Journal of extension, 35 (1). Tersedia pada http://www.joe.org/joe/1997 february/iwl.sht.ml. Diakses pada 21 Agustus 2005; Internet.

Sundayana, R. (2016). Kaitan antara gaya belajar, kemandirian belajar, dan kemampuan pemecahan masalah siswa SMP dalam pelajaran matematika. Jurnal mosharafa, 8(1); 31-40.

Wahyuningsih, S.S, Rusli, Y., \& Bintari, A. (2015). Aksesibilitas mahasiswa pada tutorial online program studi perpustakaan. Jurnal pendidikan terbuka dan jarak jauh, 16 (1); 29-38. 